\title{
Soil macrofauna as bioindicator of the recovery of degraded Cerrado soil
}

\author{
Aline Emy Kitamura1 ${ }^{1}$ (D) Rose Luiza Moraes Tavares ${ }^{2 *}$ (D) Marlene Cristina Alves ${ }^{1}$ (D) \\ Zigomar Menezes de Souza $^{3}$ (i) Diego Silva Siqueira ${ }^{4}(\mathbb{C}$
}

${ }^{1}$ Faculdade de Engenharia, Universidade Estadual Paulista (UNESP), São Paulo, SP, Brasil.

${ }^{2}$ Faculdade de Agronomia, Universidade de Rio Verde (UniRV), 13073-540, Rio Verde, GO, Brasil. E-mail: roseluiza@unirv.edu.br. *Corresponding author.

${ }^{3}$ Faculdade de Engenharia Agrícola (UNICAMP), Campinas, SP, Brasil.

${ }^{4}$ Núcleo de Inovação Tecnológico do Supera Parque de Tecnologia, Ribeirão Preto, SP, Brasil.

ABSTRACT: The construction of the hydroelectric power plant of Ilha Solteira, in state of São Paulo, was initiated in the 1960s, when an average, $8.60 \mathrm{~m}$ of soil depth was removed, resulting in a degraded area. A plan for the recovery of the area started in 2005 in Selviria I $M S$ with the use of plant species adapted to the Cerrado biome. This study aimed to evaluate the soil macrofauna of an area under recovery by using different types of soil cover (1- bare soil (control); 2- native Cerrado vegetation; 3- specie Astronium fraxinifolium; 4- Astronium fraxinifolium + Canavalia ensiformis; 5- Astronium fraxinifolium + Raphanus sativus; 6- Astronium fraxinifolium + Brachiaria decumbens + sewage sludge). Soil macrofauna was evaluated in 2005, 2006 and 2007 using the direct collection method and manual counting. Number of species, diversity and uniformity index were determined. Principal component analysis (PCA) and cluster analysis were used for data interpretation. Results showed that treatment 6 (Astronium fraxinifolium + Brachiaria decumbens + sewage sludge) increased the soil macrofauna population by approximately 4 to 6 times more than the other types of cover after three years of evaluation. And the PCA and cluster analysis showed the approximation of the data between treatment 6 and Cerrado, which represents the most appropriate treatment for the recovery of the degraded soil. Key words: bioindicators, uniformity, principal component analysis, cluster analysis.

Macrofauna do solo como bio indicador da recuperação de um solo degradado de Cerrado

RESUMO: A construção da usina hidrelétrica de Ilha Solteira, no interior de São Paulo, foi iniciada nos anos 1960, quando foi retirado, em média, 8,60 m de solo em profundidade, dando origem a uma área degradada. Com isso, iniciou-se em 2005 um plano de recuperação da área no municipio de Selvíria/MS com plantio de espécies vegetais adaptadas ao bioma Cerrado. Assim, este trabalho teve como objetivo avaliar a macrofauna do solo de uma área em processo de recuperação com plantio de diferentes tipos de cobertura vegetal (1-solo nu (testemunha); 2- vegetação nativa de Cerrado; 3- espécie arbórea Astronium fraxinifolium; 4-Astronium fraxinifolium + Canavalia ensiformis; 5- Astronium fraxinifolium + Raphanus sativus; 6- Astronium fraxinifolium + Brachiaria decumbens + lodo de esgoto). A macrofauna de solo foi avaliada em 2005, 2006 e 2007 utilizando o método de coleta direta e contagem manual. Foram determinados: quantidade de espécies e indices de diversidade e uniformidade. As análises de componentes principals (PCA) e de cluster foram utilizadas para interpretação de dados. Os resultados mostraram que o tratamento 6 (Astronium fraxinifolium + Brachiaria decumbens + lodo de esgoto) aumentou a população de macrofauna do solo em aproximadamente 4 a 6 vezes mais que os demais tipos de cobertura vegetal após três anos de avaliação. As análises de PCA e de cluster mostraram aproximação dos dados do tratamento 6 às condições ambientais naturais de Cerrado, indicando ser o tratamento mais adequado para a recuperação do solo degradado.

Palavras-chave: bio indicadores, uniformidade, componentes principais, análise de cluster.

\section{INTRODUCTION}

In the study of ecosystems, soil macrofauna play a special role in the soil food chain, by accelerating population growth and activity of microorganisms or intensifying the activity of microbial populations responsible for mineralization and humification of organic matter, and for the supply of plant-available nutrients (KORBOULEWSKY et al., 2016). Soil macrofauna also contribute strongly to soil structuring by influencing the mixture of organic and mineral particles, the redistribution of 
organic matter, and the production of "fecal pellets" (BALOTA, 2017).

In this context, the environmental balance of the soil can be evaluated by observing the populations of groups of specific organisms that are considered bioindicators of soil quality based on the degree of change in the area (OLIVEIRA FILHO et al., 2014). Living soil organisms have a high sensitivity to react to changes in soil use and management, particularly to changes in vegetation cover in addition to the case of evaluation methods (KAMAU et al., 2017; POMPEO et al., 2016; SILVA et al., 2013).

In the study of ALMEIDA et al. (2017) emphasized that the monitoring of soil macrofauna proved to be an excellent strategy to indicate environmental quality due to the relative abundance and diversity of soil fauna groups. In addition, KORBOULEWSKY et al. (2016) showed that the abundance and diversity of soil organisms are strongly affected by the presence of certain tree species. Moreover, the soil organism community structure is in most cases significantly affected by an increase in tree richness or by a mixing effect.

Among the soil ecological bioindicators, soil macrofauna consists of invertebrates with body diameters higher than $4 \mathrm{~mm}$, represented by groups of earthworms, larva and adult beetles, centipedes, termites, ants, diplopods, isopods, and arachnids (SWIFT et al., 1979). These organisms present relevant functions in the soil, such as movement of waste in the soil depth, construction of mounds, galleries and nests, ingestion and excretion of organic materials, participation in biogeochemical cycles, nutrient availability, and contribution to soil structure.

The mobility of these species is great and they play an important role in the soil by transporting materials to variable soil depths. According to some studies (BALOTA, 2017, CREPALDI et al., 2014), several groups of organisms of the soil macrofauna, such as earth worms, termites and ants, have been used as bioindicators for reflecting the soil quality status. In studies on soil communities, the measurement of the abundance and diversity of the species or groups is essential to determine their size by measuring biomass production and species richness and evenness of distribution of individuals among groups.

In degraded areas, soil recovery can be stimulated by implementing fast-growing vegetation cover species, which enable the establishment of soil organisms that improve the soil physical, chemical, and microbiological properties of the soil (KAMAU et al., 2017) This is necessary because the heavy and inappropriate exploitation of areas has contributed to a sharp decline in natural soil quality (OLIVEIRA FILHO et al., 2014). Therefore, this study evaluated the macrofauna in a degraded Oxisol under different management systems regarding soil cover over three consecutive years.

\section{MATERIALS AND METHODS}

\section{Experimental area}

The study area is located on the Plateau of the Sedimentary Basin of the Paraná River, on the right bank of the Paraná River, in the municipality of Selvíria (Mato Grosso do Sul, Brazil) (latitude $20^{\circ} 22^{\prime} 40^{\prime}$ S, longitude 5124'41.90" W, average elevation 338 masl). According to Thornthwaite (FEDDEMA, 2013), the climate is of type C2dA'a', characterized as tropical wet with rainy summers and dry winters. The relief is flat to gently rolling, with very gentle slopes. According to EMBRAPA (2013), the soil is classified as an alic, medium-textured, very deep Oxisol. The activity of the clay fraction is low, dominated essentially by gibbsite and kaolinite.

The construction of the hydroelectric power plant of Ilha Solteira, in the state of São Paulo, was initiated in the 1960s. Soil superficial layers were removed for ground leveling and foundation of the dam, which resulted in the degradation of the area. A layer with an average thickness of $8.60 \mathrm{~m}$ was removed from the original soil profile, leaving exposed part of the B-horizon. According to the Detailed Survey of Soils of the Experimental Campus of Ilha Solteira (DEMATTÊ, 1980), the thickness of the A horizon of the Oxisol under study is $30 \mathrm{~cm}$ and that of the B horizon is more than $170 \mathrm{~cm}$. Therefore, this study dealt with the subsoil on the remaining B horizon.

At the beginning of the study, the subsoil of the study area had been exposed since 1969, demonstrating surface compaction and sparse spontaneous vegetation. In 1992, treatments were implanted for soil recovery. Initially, the chemical and physical characterization of the subsoil was performed.

\section{Treatments}

The following recovery treatments of the area were installed in February 2004: 1- control - bare soil (no management); 2- native vegetation (Cerrado); 3- only tree species Astronium fraxinifolium(AF); 4- Astronium fraxinifolium + Canavalia ensiformis (AF+EC); 5- Astronium fraxinifolium + Raphanus sativus (AF+RS); 6- Astronium fraxinifolium + Brachiaria decumbens + sewage sludge (at a dose of $\left.60 \mathrm{tha}^{-1}\right)(\mathrm{AF}+\mathrm{B}+\mathrm{LE})$. As for the treatments, the area was prepared by clearing the surface, soil subsoiling 
and disking (plowing and leveling), and application of dolomitic limestone (2.0 $\left.\mathrm{Mg} \mathrm{ha}^{-1}\right)$.

The species Astronium fraxinifolium was chosen for being native to the Cerrado and since seedlings can easily be grown in nurseries. A total of 25 plants per plot were spaced $3.0 \mathrm{~m} \mathrm{x} 2.0 \mathrm{~m}$, of which the nine central plants per plot were evaluated. Jack beans (Canavalia ensiformis), oilseed radish (Raphanus sativus) and Crotalaria juncea were sown in December-January of each year. At the beginning of flowering, plants were mowed and left on the soil surface. Grass seeds (Brachiaria decumbens) were sprinkled in an area of native forest near the experimental site used for the Cerrado treatment.

The sewage sludge samples, provided by SANEAR (Sewage system of Araçatuba), in Araçatuba, state of São Paulo, which consisted predominantly of domestic effluent with $0.84 \mathrm{~kg} \mathrm{~kg}^{-1}$ moisture, were spread by hand on the soil surface and incorporated with a disk harrow.

\section{Evaluation}

Soil macrofauna was evaluated 18 months after the implementation of the treatments, using the direct collection method (ANDERSON \& INGRAM, 1993 ) and a $0.30-\mathrm{m}$ metallic square driven into the ground. Soil macrofauna was sampled carefully between the planting rows at a distance of $0.30 \mathrm{~m}$ from the plant, in the layers $0.00-0.05,0.05-0.10$ and $0.10-0.15 \mathrm{~m}$. Worms were separated from the other invertebrates and conserved in $4 \%$ formaldehyde. After separation, the remaining microorganisms were conserved in $70 \%$ alcohol. Soil macrofauna was separated and quantified, analyzing the contents of the flask from each treatment in a Petri dish under stereomicroscope. The amount of animals present in each soil sample was registered in a standardized form.

The Shannon diversity (PIELOU, 1975) and evenness indices (PIELOU, 1969) were calculated by the formulas:

$$
H^{\prime}=-\sum_{i=1}^{n} P i \ln P i E_{=} \frac{H^{\prime}}{H^{\prime} m a ́ x}
$$

in which, $\mathrm{H}^{\prime}=$ Shannon diversity index; $\mathrm{Pi}$ $=n i / \mathrm{N} ; \mathrm{ni}=$ number of individuals of the species $\mathrm{i} ; \mathrm{N}$ $=$ total number of sampled individuals; $\ln =$ Napierian logarithm, E = evenness; H' $\max =\ln \mathrm{S}$; and $\mathrm{S}=$ number of sampled species.

\section{Statistical analysis}

The experiment was arranged in a randomized block design, with six treatments and five replications in February 2004, with $150 \mathrm{~m}^{2}$ plots $(15 \mathrm{~m}$ $\mathrm{x} 10 \mathrm{~m})$. The data were analyzed using SAS software
(SCHLOTZHAVER \& LITTELL, 1997), according to the statistical model of subdivided plots (Factor 1: treatments - management systems and Factor 2: year of sampling), which was evaluated independently for each soil layer. To evaluate significant interactions, the Tukey test was applied at 5\% significance level to compare treatment means, and the original data were transformed by the function observation +1 .

Principal component analysis (PCA) was applied considering the 18 macroorganisms reported in the macrofauna in the different treatments over the three years of evaluation. It was used to verify which elements of the macrofauna were related to the different treatments. This technique explains the covariance structure of a set of variables based on a few linear combinations of the variables (JOHNSON \& WICHERN, 2002).

Results were subjected to hierarchical cluster analysis as proposed by SNEATH \& SOKAL (1973). The objective of this analysis was to verify similarities regarding macrofauna of the treatments. Similarity coefficients were calculated from the Euclidean distance (HAIR et al., 2005) using the same data as for PCA. Clusters were based on the full connection algorithm (MARDIA et al., 1997). In this method, the researcher establishes the cluster level according to an easily understandable criterion. The Euclidean distance used in this study was 7.75 and 2.25. The PCA and cluster analysis were performed using Statistica 7.0 software.

\section{RESULTS AND DISCUSSION}

\section{Effect of treatments on the quantity of macrofauna}

The quantity of soil macrorganisms increased $p<0.05$ ) after three years of cultivation of the studied plant species, especially in areas with $\mathrm{AF}+\mathrm{B}+\mathrm{LE}$ (Astronium fraxinifolium + Brachiaria decumbens + sewage sludge) and under Cerrado native vegetation, which presented $95 \%$ more organisms on the soil surface $(0.05-0.10 \mathrm{~m})$ than the soil area SWM (soil without cover management) (Table 1).

The presence of cover vegetation on soil provides greater food availability and; consequently, the establishment of taxonomic groups aiming to colonize the soil, improving the physical structure and acting in the initial decomposition processes of plant residues. With the increase in the colonization of edaphic fauna in the areas under recovery, the organisms reach a near or higher standard than under native vegetation (OLIVEIRA FILHO et al., 2014).

The soil layers $0.05-0.10$ and $0.10-0.15 \mathrm{~m}$ presented the same trend observed for layer $0.00-0.05$ 
Table 1 - Amount of soil organisms in soil - density $\left(\right.$ indm $\left.^{-2}\right)$ in different management systems, year of counting and soil layer.

\begin{tabular}{|c|c|c|c|c|}
\hline System & 2005 & 2006 & 2007 & Mean \\
\hline \multicolumn{5}{|c|}{ } \\
\hline SWM & $20.0 \mathrm{cB}$ & $8.8 \mathrm{cB}$ & $26.6 \mathrm{cA}$ & 18.44 \\
\hline CERR & $348.8 \mathrm{aB}$ & $420.0 \mathrm{aB}$ & $728.8 \mathrm{aA}$ & 388.11 \\
\hline $\mathrm{AF}$ & $20.0 \mathrm{cB}$ & $135.5 \mathrm{bA}$ & $22.2 \mathrm{cB}$ & 59.2 \\
\hline $\mathrm{AF}+\mathrm{CE}$ & $8.88 \mathrm{cA}$ & $13.3 \mathrm{cA}$ & $26.6 \mathrm{cA}$ & 16.22 \\
\hline $\mathrm{AF}+\mathrm{RS}$ & $20.0 \mathrm{cB}$ & $15.5 \mathrm{cB}$ & $86.6 \mathrm{bA}$ & 40.66 \\
\hline $\mathrm{AF}+\mathrm{B}+\mathrm{LE}$ & $51.1 \mathrm{bC}$ & $177.7 \mathrm{bB}$ & $946.6 \mathrm{aA}$ & 391.77 \\
\hline Mean & 78.1 & 128.4 & 306.2 & \\
\hline \multicolumn{5}{|c|}{ 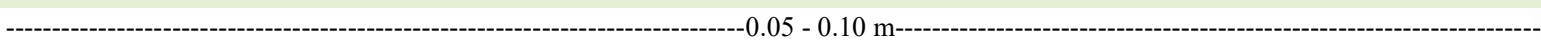 } \\
\hline SWM & $13.1 \mathrm{cB}$ & $22.2 \mathrm{cA}$ & $42.2 \mathrm{cA}$ & 25.8 \\
\hline CERR & $360.0 \mathrm{aA}$ & $135.5 \mathrm{aB}$ & $151.1 \mathrm{bAB}$ & 215.5 \\
\hline $\mathrm{AF}$ & $3.3 \mathrm{cB}$ & $40.0 \mathrm{cAB}$ & $155.5 \mathrm{bA}$ & 52.5 \\
\hline $\mathrm{AF}+\mathrm{CE}$ & $6.6 \mathrm{cA}$ & $46.6 \mathrm{cA}$ & $46.6 \mathrm{cA}$ & 33.3 \\
\hline $\mathrm{AF}+\mathrm{RS}$ & $6.6 \mathrm{cA}$ & $6.6 \mathrm{dA}$ & $93.3 \mathrm{bA}$ & 35.5 \\
\hline $\mathrm{AF}+\mathrm{B}+\mathrm{LE}$ & $26.6 \mathrm{bB}$ & $84.4 \mathrm{bB}$ & $415.5 \mathrm{aA}$ & 175.5 \\
\hline Mean & 69.2 & 55.8 & 144 & \\
\hline \multicolumn{5}{|c|}{ 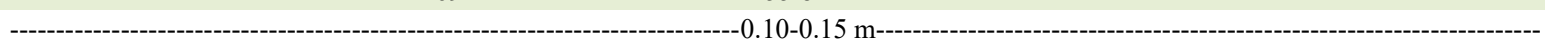 } \\
\hline SWM & $17.7 \mathrm{bB}$ & $33.3 \mathrm{bB}$ & $166.6 \mathrm{bA}$ & 54.5 \\
\hline CERR & $297.7 \mathrm{aA}$ & $171.1 \mathrm{aB}$ & $113.3 \mathrm{bB}$ & 194.1 \\
\hline $\mathrm{AF}$ & $6.6 \mathrm{cB}$ & $53.3 \mathrm{bA}$ & $31.1 \mathrm{cA}$ & 30.3 \\
\hline $\mathrm{AF}+\mathrm{CE}$ & $8.8 \mathrm{cC}$ & $37.7 \mathrm{bB}$ & 197.7 bA & 81.4 \\
\hline $\mathrm{AF}+\mathrm{RS}$ & $13.3 \mathrm{bB}$ & $15.5 \mathrm{cB}$ & $68.8 \mathrm{cA}$ & 32.5 \\
\hline $\mathrm{AF}+\mathrm{B}+\mathrm{LE}$ & $20.0 \mathrm{bB}$ & $40.0 \mathrm{bB}$ & $246.6 \mathrm{aA}$ & 102.2 \\
\hline Mean & 60.6 & 58.5 & 233.83 & \\
\hline
\end{tabular}

$\mathrm{SWM}=$ soil without management $\mathrm{CERR}=$ Cerrado; $\mathrm{AF}=$ Astronium fraxinifolium $; \mathrm{AF}+\mathrm{CE}=$ Astronium fraxinifolium + Canavalia ensiformis; $\mathrm{AF}+\mathrm{RS}=$ Astronium fraxinifolium + Raphanuss ativus $; \mathrm{AF}+\mathrm{B}+\mathrm{LE}=$ Astronium fraxinifolium + Brachiaria decumbens + sewage sludge. Means followed by identical letters (lowercase in the row and uppercase in the column) in each soil depth do not differ by the Tukey test at $5 \%$ probability.

$\mathrm{m}$, in which the treatments $\mathrm{AF}+\mathrm{B}+\mathrm{LE}$ (Astronium fraxinifolium + Brachiaria decumbens + sewage sludge) and Cerrado promoted greater number of macrorganisms $(\mathrm{p}<0.05)$ in the soil when compared with areas with AF cultivated alone or intercropped with other species (Table 1).

The mean value of density population on the soil surface $(0.00-0.05 \mathrm{~m})$ in the area with $\mathrm{AF}+$ $\mathrm{B}+\mathrm{LE}$ was 946 indm $^{-2}$, which is close to the value reported by Oliveira Filho et al. (2014) (up to 925 ind $\mathrm{m}^{-2}$ ) in an area under recovery (with history of coal exploration) using grass (Cymbopogon sp).

This result indicated a positive effect of Astronium fraxinifolium with Brachiaria decumbens combination, which are species adapted to the Cerrado biome. The use of brachiaria might have favored the emergence of organisms due to the greater layer of dry matter in different degrees of decomposition, sheltering organisms with different survival strategies. The potential use of brachiaria to increase edaphic fauna was detected by RODRIGUES et al. (2016), with a predominance of species of the orders Aranae, Coleoptera and Diptera.

In addition, the use of sewage sludge might have accelerated the biota recovery process through improvements soil habitat by increase of organic matter, as demonstrated by KITAMURA et al. (2008), when studying the same area of the present research. ALMEIDA et al. (2017) showed that land use systems with constant addition of organic waste enable greater abundance of soil organisms.

Overall, there was an accelerated increase of the macrofauna population in three years, indicating improvements in soil quality, as the process of organic waste decomposition and subsequent soil organic matter increase occur through the action of soil organisms (macro- and microorganisms). The treatment Astronium fraxinifolium + Brachiaria 
decumbens + sewage sludge contributed most to increase the soil macrofauna population. Thus, it was best suited for the recovery of the degraded area under study.

\section{Diversity of soil macrofauna}

The Shannon index $(\mathrm{H})$ indicates the diversity of the macrofauna population, while the evenness index (E) indicates the uniformity of the species distribution. Thus, the higher the Shannon index and the closer to 1 the evenness index, the better the soil biological quality. The following organisms were reported: Coleoptera (beetle),Chilopoda (centipede), Arachnida (spider), Haplotaxida (earthworm), Isoptera(termite), Scarabaeidae larva, Formicidae (ant), Diplopoda (millipedes), Dermaptera (earwing), and Blattodea (cockroach).

Generally, the area treated with $\mathrm{AF}+\mathrm{B}+\mathrm{LE}, \mathrm{AF}+\mathrm{RS}$ and the Cerrado area showed greater biological diversity (Table 2), which can be reaffirmed by KITAMURA et al (2008), reinforcing the good effect of the combination $\mathrm{AF}+\mathrm{B}+\mathrm{LE}$ in the increase and diversification of the soil biota, providing greater resilience of soil, that is, the capacity of the adopted system to 215 recover the balance after being disturbed, expressing its restoration capacity. It is possible that diversity of species in these areas is linked to the use of sewage sludge. For example, CREPALDI et al. (2014) and POMPEO et al. (2016) reported a positive correlation between the content of organic matter and the diversity of species.

Regarding the balance of macrorganisms, the area with $\mathrm{AF}+\mathrm{RS}$ presented greater uniformity of individual distribution. While in the area with $\mathrm{AF}+\mathrm{B}+\mathrm{LE}$, there was predominance of Formicidae (ant) and larvae, and in the area under Cerrado, a greater amount of Formicidae and Isoptera (termite). Similarly, OLIVEIRA et al. (2014) detected a predominance of ants in the soil of area under recovery process.

The presence of ants in the $\mathrm{AF}+\mathrm{B}+\mathrm{LE}$ and Cerrado areas indicate a positive aspect in the initial establishment of the edaphic fauna, because, according to CREPALDI et al. (2014), the ants are bioindicators

Table 2 - Shannon diversity $(\mathrm{H})$ and equitability $(\mathrm{E})$ index calculated to treatments at three years and for different soil depth in Selvíria / MS.

\begin{tabular}{|c|c|c|c|c|c|c|}
\hline \multirow[t]{2}{*}{ System } & \multicolumn{2}{|c|}{-------------------2005---------------- } & \multicolumn{2}{|c|}{--------------------2006----------------- } & \multicolumn{2}{|c|}{-------------------2007------------------ } \\
\hline & $\mathrm{H}$ & E & $\mathrm{H}$ & $\mathrm{E}$ & $\mathrm{H}$ & E \\
\hline \multicolumn{7}{|c|}{ 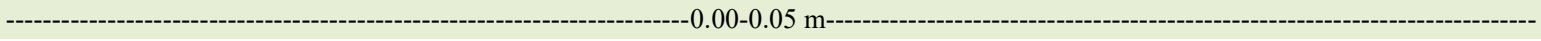 } \\
\hline SWM & 0.00 & 0.00 & 0.56 & 0.28 & 0.88 & 0.55 \\
\hline CERR & 0.95 & 0.53 & 1.69 & 0.77 & 0.73 & 0.33 \\
\hline $\mathrm{AF}$ & 1.09 & 0.79 & 1.11 & 0.62 & 1.26 & 0.65 \\
\hline $\mathrm{AF}+\mathrm{CE}$ & 0.56 & 0.81 & 0.87 & 0.79 & 1.24 & 0.77 \\
\hline $\mathrm{AF}+\mathrm{RS}$ & 1.52 & 0.95 & 0.60 & 0.86 & 1.50 & 0.93 \\
\hline $\mathrm{AF}+\mathrm{B}+\mathrm{LE}$ & 1.12 & 0.69 & 1.52 & 0.78 & 1.50 & 0.63 \\
\hline \multicolumn{7}{|c|}{ - } \\
\hline SWM & 0.90 & 0.82 & 0.67 & 0.34 & 1.40 & 0.87 \\
\hline CERR & 0.58 & 0.32 & 1.32 & 0.63 & 2.06 & 0.86 \\
\hline $\mathrm{AF}$ & 0.00 & 0.00 & 1.19 & 0.74 & 1.22 & 0.76 \\
\hline $\mathrm{AF}+\mathrm{CE}$ & 1.04 & 0.95 & 0.19 & 0.28 & 1.40 & 0.72 \\
\hline $\mathrm{AF}+\mathrm{RS}$ & 0.64 & 0.92 & 0.64 & 0.92 & 1.23 & 0.89 \\
\hline $\mathrm{AF}+\mathrm{B}+\mathrm{LE}$ & 0.89 & 0.81 & 0.96 & 0.69 & 1.22 & 0.59 \\
\hline \multicolumn{7}{|c|}{ 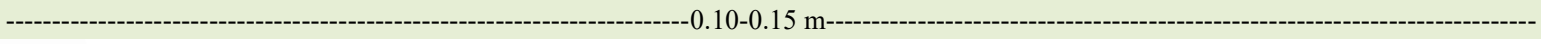 } \\
\hline SWM & 0.35 & 0.50 & 0.85 & 0.28 & 0.68 & 0.62 \\
\hline CERR & 0.52 & 0.32 & 0.85 & 0.61 & 1.44 & 0.60 \\
\hline $\mathrm{AF}$ & 0.67 & 0.34 & 0.79 & 0.72 & 1.25 & 0.90 \\
\hline $\mathrm{AF}+\mathrm{CE}$ & 0.97 & 0.89 & 0.44 & 0.40 & 1.60 & 0.89 \\
\hline $\mathrm{AF}+\mathrm{RS}$ & 0.90 & 0.82 & 0.60 & 0.86 & 1.16 & 0.84 \\
\hline $\mathrm{AF}+\mathrm{B}+\mathrm{LE}$ & 1.27 & 0.92 & 0.79 & 0.72 & 0.62 & 0.45 \\
\hline
\end{tabular}

$\mathrm{SWM}=$ soil without management $; \mathrm{CERR}=\mathrm{Cerrado} ; \mathrm{AF}=$ Astronium fraxinifolium $; \mathrm{AF}+\mathrm{CE}=$ Astronium fraxinifolium + Canavalia ensiformis; $\mathrm{AF}+\mathrm{RS}=$ Astronium fraxinifolium + Raphanuss ativus $; \mathrm{AF}+\mathrm{B}+\mathrm{LE}=$ Astronium fraxinifolium + Brachiaria decumbens + sewage sludge. Bold highlight for top I and $\mathrm{H}$ index. 
of quality in natural systems, for presenting great sensitivity to the changes of the environment with important functions in the soil as fragmentation and redistribution of organic residues in the soil depth. This process alters the soil structure with the creation of galleries, formation of biogenic structures (excrement and mounds) that help in the macroaggregates formation, providing more stable structures and improving the pore space (BALOTA, 2017).

In the subsurface soil layers (0.05-0.10 and $0.10-0.15 \mathrm{~m}$ ), there was variation in the Shanonn indices and evenness. Generally, for the second and third year, the greatest biological diversity was in the Cerrado soil and better distribution of soil species was $\mathrm{AF}+\mathrm{RS}$. A large part of soil fauna activities occurs at the soil-litter interface, which is a habitat that acts as a source of carbon and energy for these organisms (BALOTA, 2017).

\section{Multivariate structure}

Literature recommends interpretations to use a total number of principal components (PCs) that explain at least $70 \%$ of the total variance of the data (CARVALHO JÚNIOR et al., 2008). For this study,
PC1 explained 54.41\% and PC2 31.26\%, with a total of $85.67 \%$.

Figure 1 shows the interaction of macrofauna with the different treatments analyzed by PCA and the preference of different macrofauna species in the treatments. Treatment $A F+B+L E$ provided a favorable habitat for the development of populations and it was the closest treatment to the natural Cerrado habitat in terms of population development. Conversely, the treatments $\mathrm{AF}+\mathrm{RS}$, $\mathrm{AF}+\mathrm{CE}, \mathrm{AF}$ and SWM favored only the development of groups as praying mantis and pupa populations.

Similarly, by using principal component analysis, POMPEU et al. (2016) identified that most of the soil fauna was associated with native vegetation systems and spontaneous vegetation, while isolated pine cultivation showed low number of associated groups.

Intensity of land use and microclimate affect edaphic organisms. Thus, the largest number of groups reported in the $\mathrm{AF}+\mathrm{B}+\mathrm{LE}$ and Cerrado systems might be related to these factors. Moreover, in the soil under Cerrado, the vegetation cover remains unchanged, which consequently guarantees smaller temperature variations, providing a more favorable

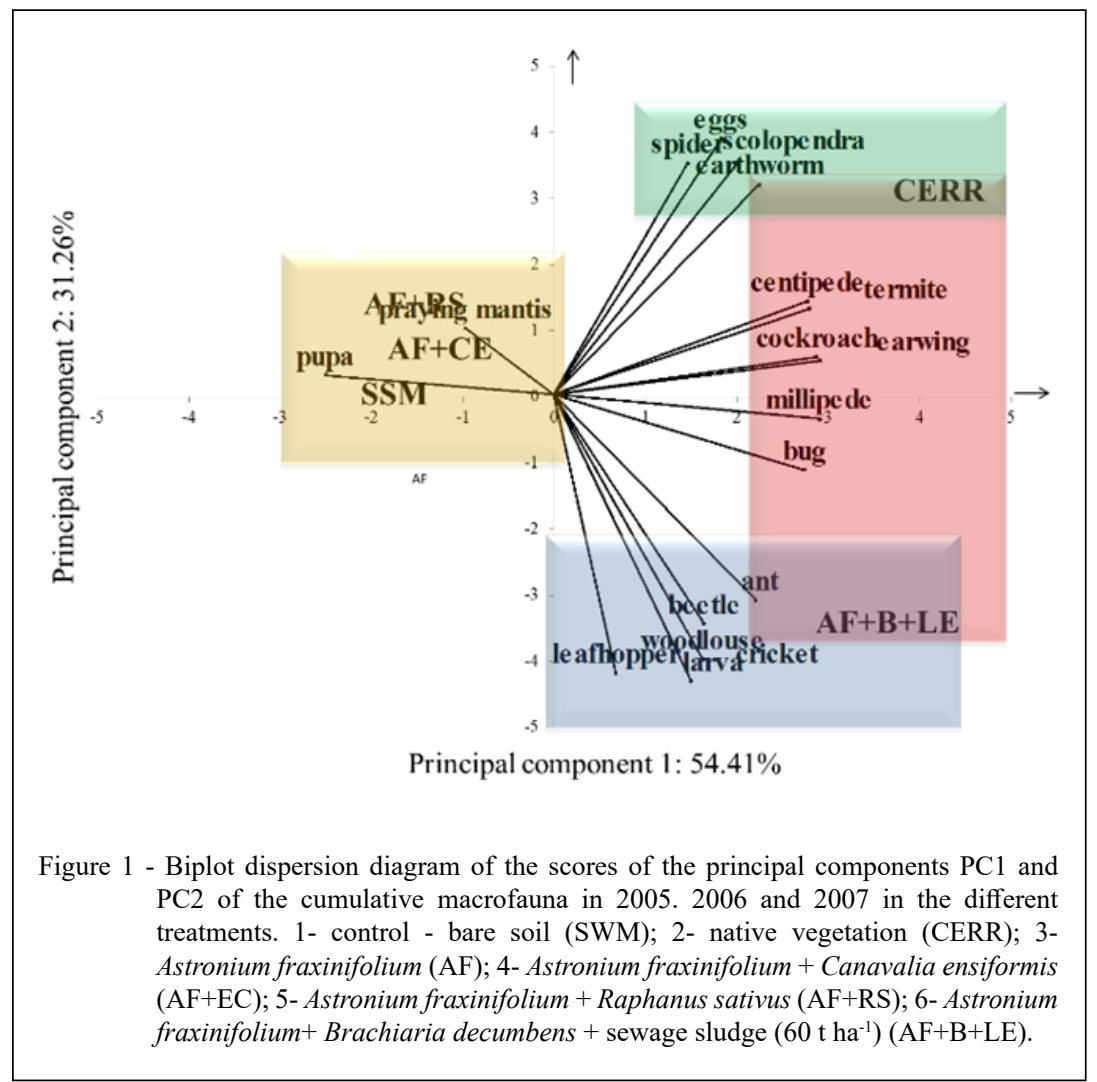

Ciência Rural, v.50, n.8, 2020. 
environment for the establishment of several groups of edaphic organisms.

The treatment $\mathrm{AF}+\mathrm{B}+\mathrm{LE}$ presented the highest population of ants, beetles, woodlice, and leafhoppers (Figure 1), while in natural vegetation, the most numerous species, considered characteristic of the region, were spiders, Scolopendra and worms. This demonstrated that there was no dominance of one or two species in the two treatments, because of the diversity of the residues on the soil in these treatments.

In addition, other species were reported in these environments (centipedes, termites, cockroaches, earwigs, millipedes, and bugs), which can be considered less selective since no preference for the Cerrado or $\mathrm{AF}+\mathrm{B}+\mathrm{LE}$ was detectable.

Figure 2 shows the result of cluster analysis using the cumulative number of species of the macrofauna in the three years of evaluation. The dendrogram shows that treatment $\mathrm{AF}+\mathrm{B}+\mathrm{LE}$ induced the most similar conditions to the natural Cerrado in relation to the total of macrospecies observed over the three years, confirming the results of the descriptive and principal component analyses. This shows the response of soil macrofauna to treatment $\mathrm{AF}+\mathrm{B}+\mathrm{LE}$, mainly by the application of sewage sludge, which increased the amount of substrate for the soil populations.

The treatment with native species, pasture and application of sewage sludge increased soil quality, which highlights the importance of maintaining a vegetation cover and supplying organic material (Figures 1 and 2). According to SILVA et al. (2013), an increase in soil macrofauna diversity results in the production of essential structures for the storage and dynamics of soil organic matter, nutrient recycling and maintenance of physical properties essential for the sustainability of primary production. Therefore, areas with a low presence of soil organisms, such as disturbed areas, unprotected soils or soil with poor vegetation cover, are detrimental to the maintenance of the soil balance and quality.

\section{CONCLUSION}

The treatment with Astronium fraxinifolium + Brachiaria decumbens + sewage sludge increased

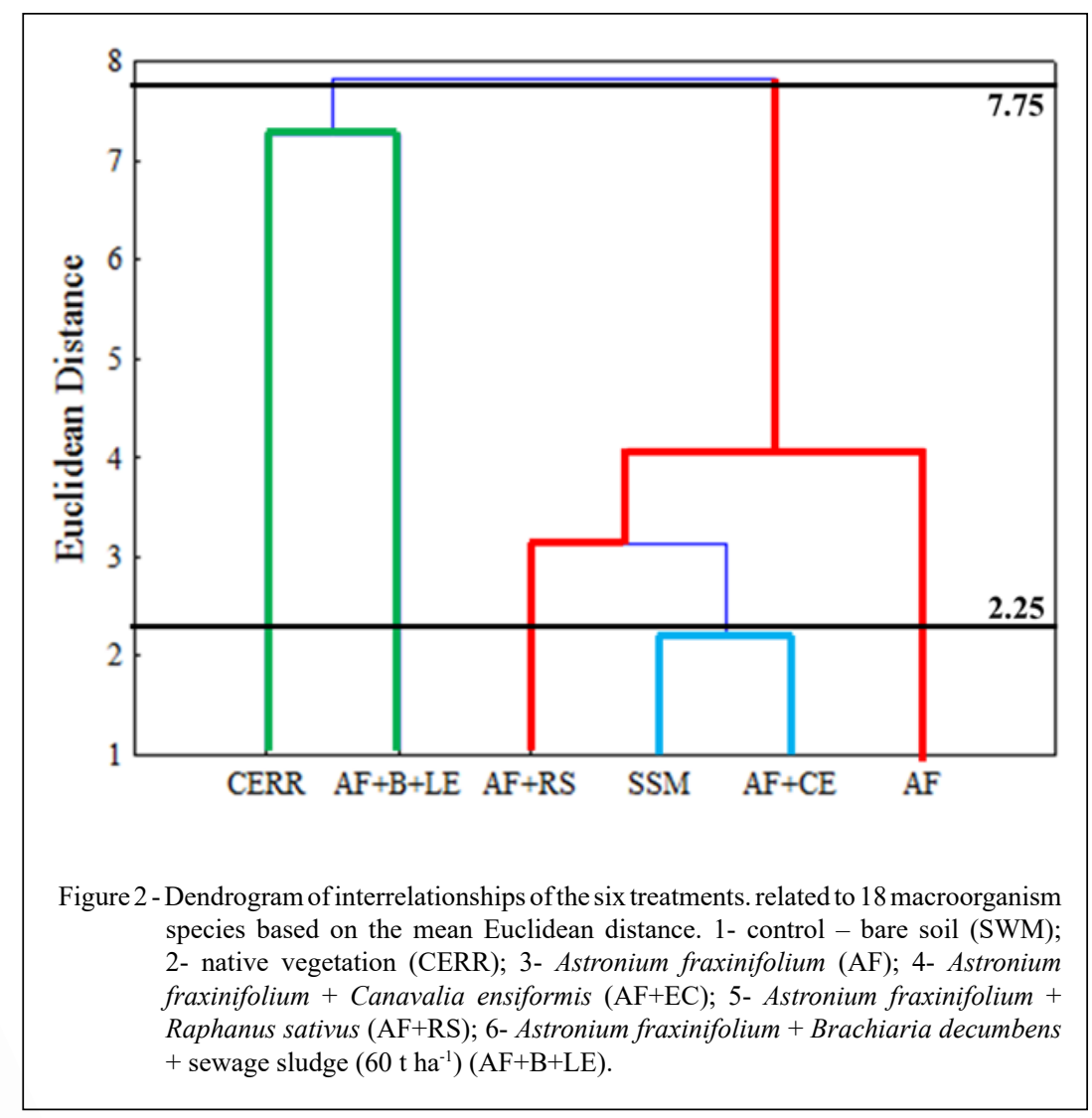

Ciência Rural, v.50, n.8, 2020. 
the soil macrofauna population, exceeding the quantity of species of the Cerrado area in 2007.Moreover, it was among the treatments with the highest species diversity. Therefore, this treatment was the most similar to the natural Cerrado environment, being considered suitable for the recovery of degraded soil in the Brazilian Cerrado.

\section{ACKNOWLEDGEMENTS}

This work was financed in part by the Coordenação de Aperfeiçoamento de Pessoal de Nívvel Superior - Brasil (CAPES) Finance Code 001".

\section{DECLARATION OF CONFLICT OF INTERESTS}

The authors declare no conflict of interest. The founding sponsors had no role in the design of the study; in the collection, analyses, or interpretation of data; in the writing of the manuscript, and in the decision to publish the results.

\section{AUTHORS' CONTRIBUTIONS}

The authors contributed equally to the manuscript.

\section{REFERENCES}

ALMEIDA H. S. et al. Ocorrência e diversidade da fauna edáfica sob diferentes sistemas de uso do solo. Revista Brasileira de Tecnologia Agropecuária, v.1, p.15-23, 2017. Available from: <http://revistas.fw.uri.br/index.php/rbdta/article/ view/2162/2269>. Accessed: Aug. 13, 2019.

ANDERSON, J. M.; INGRAM, J. S. I. Tropical soil biological and fertility: a handbook of methods. 2 ed. Oxford: Oxford University Press, $1993.221 \mathrm{p}$.

BALOTA, E. L. Manejo e Qualidade Biológica do Solo. Ed. Mecenas, Londrina/PR, 2017, 287p.

CARVALHO JÚNIOR, W. et al. Análise multivariada de Argissolos da faixa atlântica brasileira. Revista Brasileira de Ciência do Solo, v.32, p.2081-2090, 2008. Available from: <http://www.scielo.br/scielo, php?pid $=$ S0100-06832008000500029\&script $=$ sci_abstract\&tlng $=\mathrm{pt}>$. Accessed: Aug. 13, 2019. doi: 10.1590/S0100-06832008000500029.

CREPALDI, R. A. et al. Formigas como bioindicadores da qualidade do solo em sistema integrado lavourapecuária. Ciência Rural, v.44, p.781-787, 2014. Available from: <http://www.scielo. br/pdf/cr/v44n5/a14414cr6188.pdf >. Accessed: Aug. 13, 2019.

DEMATTÊ, J. L. I. Levantamento detalhado dos solos do Campus Experimental de Ilha Solteira. Piracicaba, 1980. 131p.

EMBRAPA - Empresa Brasileira de PesquisaAgropecuaria-Centro Nacional de Pesquisa de Solos. Sistema brasileiro de classificação de solos. $3^{\circ}$ ed. Rio de Janeiro: Embrapa, 2013. 353p.

FEDDEMA, J. J. A Revised Thornthwaite-Type Global Climate Classification. Physical Geography, v.6, p.442-466, 2013.
HAIR, J. F. et al. Análise multivariada de dados. Porto Alegre, Bookman, 2005. 593p.

JOHNSON, R. A.; WICHERN, D. W. Applied multivariate statistical analysis. 5 ed. Upper Saddle River, Prentice Hall, 2002. $767 \mathrm{p}$

KAMAU, S. Soil macrofauna abundance under dominant tree species increases a long a soil degradation gradiente. Soil Biology and Biochemistry, v.112, p.35-46, 2017. Available from: $\quad<$ https://www.sciencedirect.com/science/article/abs/pii/ S003807171630459X>. Accessed: Aug. 13, 2019. doi: 10.1016/j. soilbio.2017.04.016.

KORBOULEWSKY, N. et al. How tree diversity affects soil fauna diversity: A review. Soil Biololy and Biochemistry, v.94, p.94-106, 2016. Available from: <https://www.sciencedirect.com/ science/article/abs/pii/S0038071715004174>. Accessed: Aug. 13, 2019. doi: 10.1016/j.soilbio.2015.11.024

KITAMURA, A. M. et al. Recuperação de um solo degradado com a aplicação de adubos verdes e lodo de esgoto. Revista Brasileira de Ciência do Solo, v.32, p.405-416, 2008. Available from: <http://www.scielo.br/scielo.php?pid=S0100$06832008000100038 \&$ script $=$ sci_abstract $\&$ tlng $=p t>$. Accessed: Aug. 13, 2019. doi: 10.1590/S0100-06832008000100038.

MARDIA, A. K. V. et al. Multivariate analysis. London, Academic Press, 1997. 518p.

OLIVEIRA FILHO, L. C. I. et al. Influência dos processos de recuperação do solo após mineração de carvão sobre a mesofauna edáfica em Lauro Müller, Santa Catarina, Brasil. Revista Biotemas, v.27, p.69-77, 2014. Available from: <https:// periodicos.ufsc.br/index.php/biotemas/article/view/21757925.2014v27n2p69>. Accessed: Aug. 13, 2019. doi: $10.5007 / 2175-7925.2014 \mathrm{v} 27 \mathrm{n} 2 \mathrm{p} 69$.

PIELOU, E. C. An introduction to mathematical ecology. New York, Wiley-Interscience, 1969. 286p.

PIELOU, E. C. Ecological diversity. New York, WileyInterscience, $1975.165 \mathrm{p}$.

SCHLOTZHAVER, S. D.; LITTELL, R. C. SAS: system for elementary statistical analysis. 2. ed. Cary, 1997. 905p.

POMPEO, P. N. et al. Fauna e suarelação com atributosedáficosem Lages, Santa Catarina - Brasil. Revista Scientia Agraria, v.17, p.42-51, 2016. Available from: <https://revistas.ufpr.br/agraria/ article/view/46535>. Accessed: Aug. 13, 2019. doi: 10.5380/rsa. v17i1.46535.

SNEATH, P. H.; SOKAL, R. R. Numerical taxonomy: the principles and practice of numerical classification. San Francisco, W. H. Freeman, 1973. 573p.

SILVA, R. F. et al. Fauna edáfica influenciada pelo uso de culturas e consórcios de cobertura do solo. Pesquisa Agropecuária Tropical, v.43, p.130-137, 2013. Available from: $\quad<$ http://www.scielo.br/scielo.php?script=sci arttext\&pid $=$ S1983-40632013000200001>. Accessed: Aug. 13, 2019. doi: 10.1590/S1983-40632013000200001.

SWIFT, M. J. et al. Decomposition in terrestrial ecosystems. Oxford: Blackwell. 1979. 372 p. (Studies in Ecology, 5). 